\title{
Tonantzitlolone cytotoxicity toward renal cancer cells is PKCO- and HSF1-dependent
}

\author{
Carole Sourbier $^{1}$, Bradley T. Scroggins ${ }^{2}$, Philip Z. Mannes ${ }^{1}$, Pei-Jyun Liao ${ }^{1}$, Karsten \\ Siems $^{3}$, Dietmar Wolf ${ }^{3}$, John A. Beutler ${ }^{4}$, W. Marston Linehan ${ }^{1}$, Leonard Neckers ${ }^{1}$ \\ ${ }^{1}$ Urologic Oncology Branch, Center for Cancer Research, National Cancer Institute, Bethesda, MD 20892, USA \\ ${ }^{2}$ Radiation Oncology Branch, Center for Cancer Research, National Cancer Institute, Bethesda, MD 20892, USA \\ ${ }^{3}$ AnalytiCon Discovery GmbH, D-14473 Potsdam, Germany \\ ${ }^{4}$ Molecular Targets Laboratory, Center for Cancer Research, National Cancer Institute, Frederick, MD 21702, USA
}

Correspondence to:

Leonard Neckers, e-mail: neckersl@mail.nih.gov

Keywords: englerin A, bryostatin, renal tumors, RCC, PKC $\theta$

Received: March 23, $2015 \quad$ Accepted: July 10, 2015

Published: July 20, 2015

\section{ABSTRACT}

\begin{abstract}
Elucidating the targets and mechanism of action of natural products is strategically important prior to drug development and assessment of potential clinical applications. In this report, we elucidated the main targets and mechanism of action of the natural product tonantzitlolone (TZL) in clear cell renal cell carcinoma (CCRCC). We identified TZL as a dual PKC $\alpha$ and PKC $\theta$ activator in vitro, although in CCRCC cells its activity was mostly PKC $\theta$-dependent. Through activation of PKC $\theta$, TZL induced an insulin resistant phenotype by inhibiting IRS1 and the PI3K/Akt pathway. Simultaneously, TZL activated the heat shock factor 1 (HSF1) transcription factor driving glucose dependency. Thus, similar to the selective PKC $\theta$ activator englerin A, TZL induces a metabolic catastrophe in CCRCC, starving cells of glucose while simultaneously increasing their glycolytic dependency.
\end{abstract}

\section{INTRODUCTION}

Multiple signaling pathways are involved in regulating cell metabolism. Several, including components of the insulin pathway, are regulated by members of the protein kinase $\mathrm{C}$ (PKC) family. The multiple isoforms of $\mathrm{PKC}$ directly or indirectly regulate diverse aspects of metabolism in an isoform specific manner [1,2]. For example, PKC $\theta$ and $-\varepsilon$ induce insulin resistance by inhibiting insulin receptor substrate 1 (IRS1) and the insulin pathway, while PKC $\delta$ and $-\lambda$ have the opposite effect and stimulate the insulin pathway by activating IRS1 [2]. PKC isoforms can also regulate additional aspects of cell metabolism, e.g. PKC $\zeta$ has recently been shown to regulate glutamine metabolism [3]. Therefore, developing isoform-specific regulators of PKCs might have useful clinical applications for metabolically deregulated diseases, including most epithelial cancers. One example of this is the recent identification of the natural product englerin
A (EA; $\mathrm{C}_{26} \mathrm{H}_{34} \mathrm{O}_{6}$ ) as a potent and selective PKC $\theta$ activator [4]. This finding is furthering our understanding of the role played by PKC $\theta$ in tumor tissues and identifies PKC $\theta$ interaction with the heat shock factor 1 (HSF1) transcription factor as a critical link between cell metabolism and cell stress response.

Tonantzitlolone $\left(\mathrm{C}_{26} \mathrm{H}_{40} \mathrm{O}_{7}\right)$ is a diterpene ester identified in 1990 from the native Mexican plant Stillingia sanguinolenta Müll. Arg. (Euphorbiaceae). The initial interest towards investigating $S$. sanguinolutea biomedical properties comes from native Mexican, Navajo, and Creek traditional use as a medicinal plant [5]. Reports have since addressed TZL's structure, absolute configuration, and total synthesis $[6,5]$. Although preliminary data have suggested that TZL might have an anticancer effect, a thorough characterization of the biological effects of TZL is lacking and its targets as well as its mechanisms of action are yet to be discovered. In this report, our goal was to identify TZL primary targets and to characterize the molecular effect of TZL on tumor cells. 


\section{RESULTS}

\section{Tonantzitlolone is a PKC activator with weak isoform selectivity}

Analysis of NCI 60 selectivity data indicated that TZL had a pattern of response very similar to englerin A, with a Pearson correlation of 0.91 at the GI-50 level of response; Table 1 [8]. All other pure compound correlations $(\mathrm{n}=9)$ above 0.8 were to englerin analogues, with one exception (\#741581, sodwanone W [7]). In addition, quantitative structure activity relationship (QSAR) analysis revealed that TZL is structurally similar to the protein kinase $\mathrm{C}$ (PKC) activator bryostatin 1 and analogues, suggesting that TZL is likely to have an effect on the protein kinase $\mathrm{C}$ (PKC) family (Tables 2 and 3; [8]). To validate these results, we used a pan-PKC kinase assay. Whole protein extracts of the clear cell renal cell carcinoma (CCRCC) cell line 786-0 were directly treated with TZL $\left(5 \mu \mathrm{M} ; 1 \mathrm{~h}\right.$ at $\left.30^{\circ} \mathrm{C}\right)$. We used the anticancer agent EA, a selective PKC $\theta$ activator [4], as a positive control. This assay revealed that TZL is a potent PKC activator (Figure 1A). Because of the variable functions of the different PKC isoforms, we assessed TZL isoform selectivity by in vitro kinase assay using purified proteins. As shown in Figure 1B, TZL efficiently activated $\mathrm{PKC} \theta$ and $\mathrm{PKC} \alpha$, but not $\mathrm{PKC} \delta$.

\section{Tonantzitlolone is a potent anti-tumor agent}

To further assess the biologic effect of TZL on the viability of tumor cells, we used the NCI-60 screen, a platform containing 60 different cancer cell lines [9]. Interestingly, TZL displayed a preferred cytotoxicity towards renal cancer cells (Figure 2). In a similar screen, EA also displayed renal selectivity [10]; however this was not seen with the pan-PKC activator bryostatin 1 (Figure 3; bryostatin's data were extracted from the public repository database CellMiner; NSC\#339555) [11]. These data suggest that the difference in toxicity might be due to a variation in isoform selectivity, and that TZL's effect might be PKC $\theta$-dependent.

\section{Tonantzitlolone cytotoxicity in renal cancer cells is PKCO-dependent}

We then sought to assess whether TZL cytotoxicity was dependent on a particular PKC isoform. Because of the direct effect of TZL on PKC $\theta$ and PKC $\alpha$ purified proteins (Figure 1B), we separately silenced these two kinases in 786-0 and A498 cells using small interference RNA prior to exposure to TZL. As shown in Figure 4A-B, silencing of PKC $\theta$ partially rescued the cells from TZL cytotoxicity while silencing of PKC $\alpha$ did not. This suggests that PKC $\theta$ expression is necessary to mediate TZL cytotoxicity. HEK293 cells are not sensitive to TZL (Figure 4A) and express low levels of PKC $\theta$ compared to 786- 0 and A498, but express robust levels of PKC $\alpha$ (Figure 4B; [6]), suggesting that TZL's effect in CCRCC cells is likely mediated by PKC $\theta$. To further evaluate the effect of TZL on PKC $\theta$ signaling pathway in CCRCC cells, we treated 786-0 and A498 CCRCC cell lines with TZL and assessed the effect of treatment on the insulin pathway. As shown in Figure 4C, TZL increased phosphorylation of IRS1 on serine 1101 (a PKC $\theta$-dependent phosphorylation site that inhibits IRS1 activity) and decreased Akt phosphorylation. Moreover, glucose uptake was also inhibited after TZL treatment in a PKC $\theta$-dependent manner $(5 \mu \mathrm{M}, 16 \mathrm{~h}$; Figure 4D), suggesting that TZL limits tumor cells access to glucose by inducing an insulin resistant phenotype via activation of PKC $\theta$.

We previously established a link between PKC $\theta$ and HSF1, a transcription factor known to induce tumor glucose dependency [12, 13], namely direct phosphorylation and heat-shock-independent activation of HSF1 by PKC $\theta$ [4]. We thus investigated whether TZL also induced a direct heat-shock-independent activation

Table 1: Compounds correlated to tonantzitlolone at GI-50 level in NCI 60 screen

\begin{tabular}{|l|c|l|}
\hline NSC\# & Pearson Correlation & Compound type \\
\hline 746861 & 0.91 & Englerin A \\
\hline 767580 & 0.88 & EA analog \\
\hline 780423 & 0.87 & EA analog \\
\hline 741581 & 0.86 & sodwanone W \\
\hline 782488 & 0.85 & EA analog \\
\hline 782490 & 0.84 & EA analog \\
\hline 778312 & 0.84 & EA analog \\
\hline 782489 & 0.83 & EA analog \\
\hline 767579 & 0.83 & EA analog \\
\hline 782483 & 0.83 & EA analog \\
\hline
\end{tabular}




\begin{tabular}{|c|c|c|c|}
\hline \# & Compound in database & Structure & Similarity, \% \\
\hline 1 & Bryostatin Analogue (8) & & 82.11 \\
\hline 2 & Bryostatin Analogue (9) & & 80.41 \\
\hline 3 & Bryostatin Analogue (1) & & 78.35 \\
\hline 4 & Bryostatin Analogue (6) & & 78.12 \\
\hline 5 & Bryostatin Analogue (3) & & 78 \\
\hline 6 & Ginkgolide (22) & & 77.78 \\
\hline 7 & $\begin{array}{l}\text { 2-[3-(1, 3-dioxan-2-yl)-1, 1-dimethyl-(E)-2-propenyl]- } \\
\text { 2-hydroxy-6-[3-hydroxy-2-methylcarbonyloxy-(2R, } \\
\text { 3R)-butyl]-4-methyloxycarbonylmethyl-(2S, 3S, 6S)- } \\
\text { tetrahydro-2H-3-pyranyl octanoate }\end{array}$ & Nace & 77.32 \\
\hline 8 & Bryostatin Analogue (2) & & 76.77 \\
\hline
\end{tabular}

of HSF1. Using an in vitro kinase assay with purified PKC $\theta$ and HSF1 proteins, we demonstrated that TZL was able to induce PKC $\theta$-dependent HSF1 phosphorylation (Figure 5A). Furthermore treatment of 786-0 cells with TZL ( $5 \mu \mathrm{M}, 24 \mathrm{~h})$ increased HSF1 transcriptional activity as measured with a luminescence-reporter plasmid assay (Figure 5B) and similarly to effects observed with EA, TZL cytotoxicity was observed only when HSF1 and PKC $\theta$ were simultaneously overexpressed in HEK293 cells (Figure 5C-5D). Also, TZL's cytotoxicity was dependent on the extracellular glucose concentration (Figure 5E). Indeed, in low glucose media (1 g/L), TZL was significantly more cytotoxic than in high glucose media $(4.5 \mathrm{~g} / \mathrm{L})$. Together these data demonstrate the ability of TZL to induce glucose dependency in CCRCC cell lines.

\section{DISCUSSION}

Understanding the intertwined role that members of the PKC family play in signaling pathways and cancer has the potential to lay the foundation for development of novel targeted therapies. The resurgent interest of the scientific community in understanding the molecular 
Table 3: List of tonantzitlolone predicted targets (QSAR; based on [8])

\begin{tabular}{|c|c|c|}
\hline Predicted Target & Compound of reference & Similarity (\%) \\
\hline \multirow{6}{*}{ PKC-lambda/iota } & Bryostatin Analogue (8) & 82.11 \\
\hline & Bryostatin Analogue (9) & 80.41 \\
\hline & Bryostatin Analogue (1) & 78.35 \\
\hline & Bryostatin Analogue (6) & 78.12 \\
\hline & Bryostatin Analogue (3) & 78 \\
\hline & $\begin{array}{l}\text { 2-[3-(1, 3-dioxan-2-yl)-1, 1-dimethyl-(E)-2-propenyl]-2- } \\
\text { hydroxy-6- [3-hydroxy-2-methylcarbonyloxy-(2R, 3R)-butyl]-4- } \\
\text { methyloxycarbonylmethyl-(2S, 3S, 6S)-tetrahydro-2H-3-pyranyl } \\
\text { octanoate }\end{array}$ & 77.32 \\
\hline \multirow{6}{*}{ PKC-epsilon } & Bryostatin Analogue (8) & 82.11 \\
\hline & Bryostatin Analogue (9) & 80.41 \\
\hline & Bryostatin Analogue (1) & 78.35 \\
\hline & Bryostatin Analogue (6) & 78.12 \\
\hline & Bryostatin Analogue (3) & 78 \\
\hline & $\begin{array}{l}\text { 2-[3-(1, 3-dioxan-2-yl)-1, 1-dimethyl-(E)-2-propenyl]-2- } \\
\text { hydroxy-6-[3-hydroxy-2-methylcarbonyloxy-(2R, 3R)-butyl]-4- } \\
\text { methyloxycarbonylmethyl-(2S, 3S, 6S)-tetrahydro-2H-3-pyranyl } \\
\text { octanoate }\end{array}$ & 77.32 \\
\hline \multirow{6}{*}{ PKC-zeta } & Bryostatin Analogue (8) & 82.11 \\
\hline & Bryostatin Analogue (9) & 80.41 \\
\hline & Bryostatin Analogue (1) & 78.35 \\
\hline & Bryostatin Analogue (6) & 78.12 \\
\hline & Bryostatin Analogue (3) & 78 \\
\hline & $\begin{array}{l}\text { 2-[3-(1, 3-dioxan-2-yl)-1, 1-dimethyl-(E)-2-propenyl]-2- } \\
\text { hydroxy-6-[3-hydroxy-2-methylcarbonyloxy-(2R, 3R)-butyl]-4- } \\
\text { methyloxycarbonylmethyl-(2S, 3S, 6S)-tetrahydro-2H-3-pyranyl } \\
\text { octanoate }\end{array}$ & 77.32 \\
\hline \multirow{6}{*}{ PKC-delta } & Bryostatin Analogue (8) & 82.11 \\
\hline & Bryostatin Analogue (9) & 80.41 \\
\hline & Bryostatin Analogue (1) & 78.35 \\
\hline & Bryostatin Analogue (6) & 78.12 \\
\hline & Bryostatin Analogue (3) & 78 \\
\hline & $\begin{array}{l}\text { 2-[3-(1, 3-dioxan-2-yl)-1, 1-dimethyl-(E)-2-propenyl]-2- } \\
\text { hydroxy-6-[3-hydroxy-2-methylcarbonyloxy-(2R, 3R)-butyl]-4- } \\
\text { methyloxycarbonylmethyl-(2S, 3S, 6S)-tetrahydro-2H-3-pyranyl } \\
\text { octanoate }\end{array}$ & 77.32 \\
\hline \multirow{4}{*}{ PKC-alpha } & Bryostatin Analogue (8) & 82.11 \\
\hline & Bryostatin Analogue (9) & 80.41 \\
\hline & Bryostatin Analogue (1) & 78.35 \\
\hline & Bryostatin Analogue (6) & 78.12 \\
\hline
\end{tabular}

(Continued) 


\begin{tabular}{|c|c|c|}
\hline Predicted Target & Compound of reference & Similarity (\%) \\
\hline & Bryostatin Analogue (3) & 78 \\
\hline & $\begin{array}{l}\text { 2-[3-(1,3-dioxan-2-yl)-1, 1-dimethyl-(E)-2-propenyl]-2- } \\
\text { hydroxy-6-[3-hydroxy-2-methylcarbonyloxy-(2R, 3R)-butyl]-4- } \\
\text { methyloxycarbonylmethyl-(2S, 3S, 6S)-tetrahydro-2H-3-pyranyl } \\
\text { octanoate }\end{array}$ & 77.32 \\
\hline PKC-alpha & Bryostatin Analogue (2) & 76.77 \\
\hline \multirow{6}{*}{ PKC-eta } & Bryostatin Analogue (8) & 82.11 \\
\hline & Bryostatin Analogue (9) & 80.41 \\
\hline & Bryostatin Analogue (1) & 78.35 \\
\hline & Bryostatin Analogue (6) & 78.12 \\
\hline & Bryostatin Analogue (3) & 78 \\
\hline & $\begin{array}{l}\text { 2-[3-(1, 3-dioxan-2-yl)-1, 1-dimethyl-(E)-2-propenyl]-2- } \\
\text { hydroxy-6-[3-hydroxy-2-methylcarbonyloxy-(2R, 3R)-butyl]-4- } \\
\text { methyloxycarbonylmethyl-(2S, 3S, 6S)-tetrahydro-2H-3-pyranyl } \\
\text { octanoate }\end{array}$ & 77.32 \\
\hline \multirow{6}{*}{ PKC-gamma } & Bryostatin Analogue (8) & 82.11 \\
\hline & Bryostatin Analogue (9) & 80.41 \\
\hline & Bryostatin Analogue (1) & 78.35 \\
\hline & Bryostatin Analogue (6) & 78.12 \\
\hline & Bryostatin Analogue (3) & 78 \\
\hline & $\begin{array}{l}\text { 2-[3-(1, 3-dioxan-2-yl)-1, 1-dimethyl-(E)-2-propenyl]-2- } \\
\text { hydroxy-6 -[3-hydroxy-2-methylcarbonyloxy-(2R, 3R)-butyl]-4- } \\
\text { methyloxycarbonylmethyl-(2S, 3S, 6S)-tetrahydro-2H-3-pyranyl } \\
\text { octanoate }\end{array}$ & 77.32 \\
\hline \multirow{6}{*}{ PKC-theta } & Bryostatin Analogue (8) & 82.11 \\
\hline & Bryostatin Analogue (9) & 80.41 \\
\hline & Bryostatin Analogue (1) & 78.35 \\
\hline & Bryostatin Analogue (6) & 78.12 \\
\hline & Bryostatin Analogue (3) & 78 \\
\hline & $\begin{array}{l}\text { 2-[3-(1, 3-dioxan-2-yl)-1, 1-dimethyl-(E)-2-propenyl]-2- } \\
\text { hydroxy-6- [3-hydroxy-2-methylcarbonyloxy-(2R, 3R)-butyl]-4- } \\
\text { methyloxycarbonylmethyl-(2S, 3S, 6S)-tetrahydro-2H-3-pyranyl } \\
\text { octanoate }\end{array}$ & 77.32 \\
\hline
\end{tabular}

mechanisms regulating the metabolism of cancer cells has shed a new light on the role of PKC in regulating metabolic processes, especially in tumor cells. Here we report that the natural product TZL is a potent PKC activator with tumor cytotoxicity that is mostly mediated by the novel PKC isoform PKC $\theta$. By activating PKC $\theta$, TZL inhibits the insulin pathway while activating HSF1 and glucose dependency.

Clear cell renal cell carcinoma is the most common type of both sporadic and hereditary kidney cancer. It is primarily induced by mutations occurring in the tumor suppressor gene VHL [14]. Defective VHL protein expression leads to stabilization of hypoxia-inducible factors 1 and $2[15,16]$, increased DNA damage [17], and to activation of the PI3K/Akt pathway stimulating cell proliferation and tumor growth [18]. Thus VHL-deficient cells display a pseudo-hypoxic phenotype with a restructured metabolism oriented toward aerobic glycolysis and favoring anabolic growth [12]. Interestingly, PKC members have been shown to be induced by hypoxia and novel PKC isoforms are known to interact with VHL, suggesting that VHL might directly regulate the expression of some of the PKC isoforms. Also, besides a well-characterized role in regulating cell cycle and survival [19, 20,21], PKC isoforms are also critical in regulating metabolic 
B
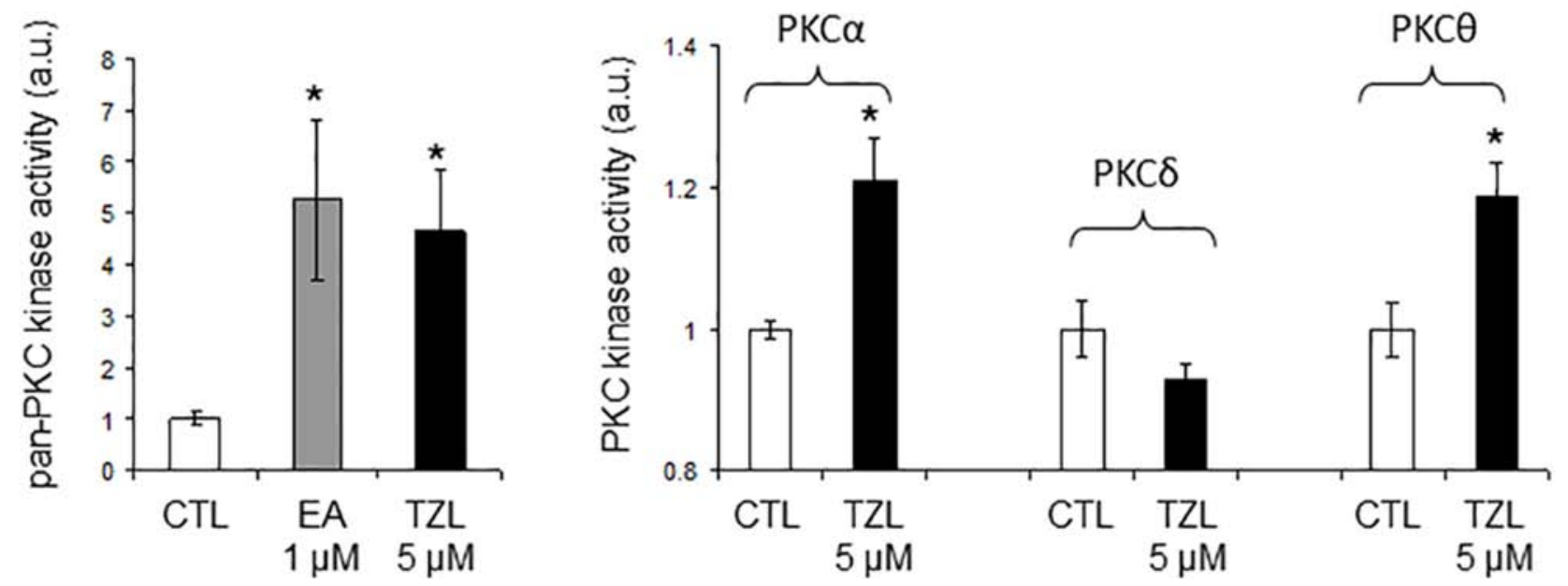

Figure 1: Tonantzitlolone is a PKC activator. A. Pan-PKC kinase activity was assessed by pan-PKC kinase assay using $30 \mu \mathrm{g}$ of whole cell extracts from the CCRCC cell line 786-0. Lysates were treated with either DMSO or TZL $\left(5 \mu \mathrm{M} ; 1 \mathrm{hr}\right.$ at $\left.30^{\circ} \mathrm{C}\right)$. B. Assessement of PKC isoform selectivity was performed following a similar protocol but using purified proteins for $\mathrm{PKC} \alpha,-\delta$, and $-\theta(5 \mathrm{ng})$. ${ }^{*} p<0.05$; EA: englerin A; TZL: Tonantzitlolone.

processes $[2,3]$. Hence, CCRCC cells are useful tools for studying PKC isoform functions.

Although structurally different from the natural product EA [5, 10], TZL has a similar profile in the NCI-60 screen suggesting that the two compounds might share a similar mechanism of action. Using in vitro kinase assays, we showed that TZL activated PKC $\theta$ and not PKC $\delta$ and that its cytotoxicity was PKC $\theta$ dependent in CCRCC cells. Because of the limited expression profile of PKC $\theta$ to some solid tumors and immune cells, and the fact that HSF1 is often overexpressed in tumors, TZL might only be lethal to PKC $\theta$-expressing, HSF1- addicted glycolytic tumor cells.

Despite the well-characterized role of HSF1 in cancer development and progression [13, 12, 22, 23], in the context of PKC $\theta$ activation and the inhibition of the insulin pathway, non-heat-shock HSF1 activation appears to provide a therapeutic advantage. HSF1 is a tumor growth facilitator that enhances tumor glucose dependence via a heat-shock-independent transcriptional program [12]. Since TZL activates HSF1 and its cytotoxicity is inversely related to extracellular glucose concentration (Figure 5E), the fact that HSF 1 increases glucose dependency might provide a rationale for why activation of HSF 1 underlies the cytotoxicity of PKC $\theta$ activators such as TZL.

In conclusion, our data suggest that TZL and the PKC $\theta$ activator EA share a similar mechanism of action in CCRCC cell lines - that is PKC $\theta$ activation that leads to a metabolic catastrophe by simultaneously inhibiting the insulin pathway via inhibitory phosphorylation of IRS1 while inducing glucose addiction via HSF1 activation. These data also further support PKC $\theta$ as a strategic therapeutic target for patients with highly glycolytic tumors, such as CCRCC.

\section{MATERIALS AND METHODS}

\section{Reagents}

Tonantzitlolone was generously supplied by AnalytiCon Discovery GmbH (Postdam, Germany). Englerin A was isolated as described from Phyllanthus engleri [9]. Complete mini-protease inhibitor cocktail tablets were purchased from Roche (Indianapolis, IA, USA). Purified HSF1, PKC $-\theta,-\alpha$, and $-\delta$ were purchased from EnzoLife Sciences (Farmingdale, NY, USA). PI3K and Akt inhibitors wortmannin, LY294002 and perifosine were from Selleck Chemicals (Houston, TX, USA).

\section{Prediction of tonantzitlolone targets}

Prediction of TZL target was performed using the software Metadrug (Genego Inc, Carlsbad, CA, USA), a systems pharmacology platform using QSAR modeling to analyze and compare biological effects of small molecule, as previously described [4]. The COMPARE algorithm was essentially as described in [8].

\section{Non-radioactive PKC kinase assay}

PKC kinase activity of cell lysates was measured using the pan-PKC activity assay from EnzoLife Sciences. Cells were lysed in TNESV lysis buffer (50 mM Tris, 1\% Nonidet P-40, 2 mM EDTA, $100 \mathrm{mM} \mathrm{NaCl}$ and $2 \mathrm{mM} \mathrm{Na}_{3} \mathrm{VO}_{4}$ ). After centrifugation $\left(15 \mathrm{~min} ; 15,000 \mathrm{rpm} ; 4^{\circ} \mathrm{C}\right)$, clarified supernatant was incubated with $10 \mu \mathrm{M}$ TZL in the kinase buffer provided by the manufacturer $\left(1 \mathrm{~h}\right.$ at $30^{\circ} \mathrm{C}$ with $10 \mu \mathrm{M}$ ATP $)$. The reaction was stopped and the phosphorylation of a PKC substrate was measured by spectrophotometry as indicated 

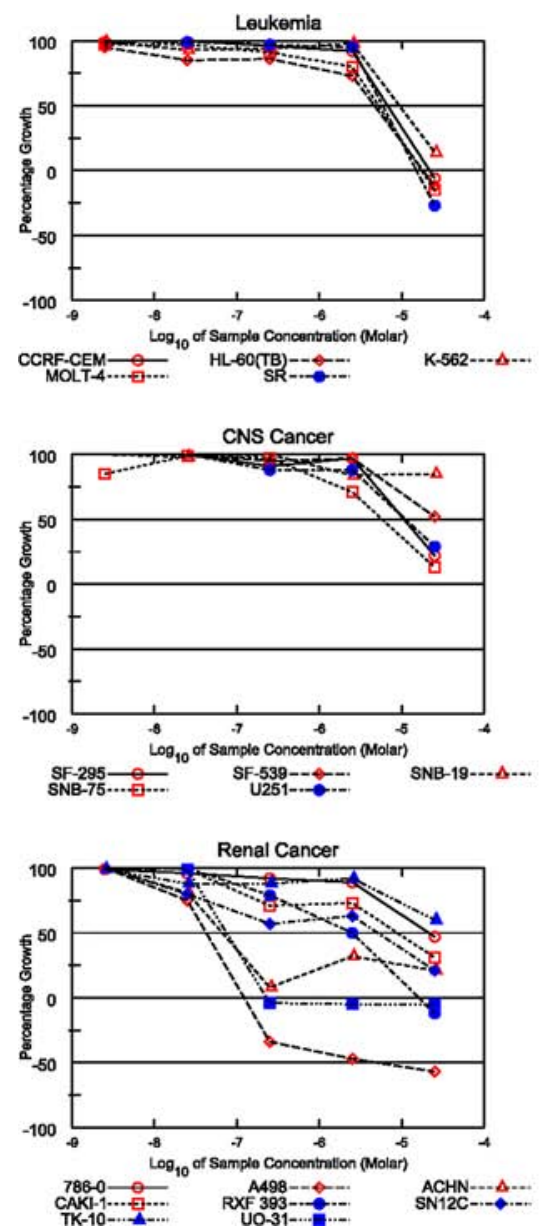
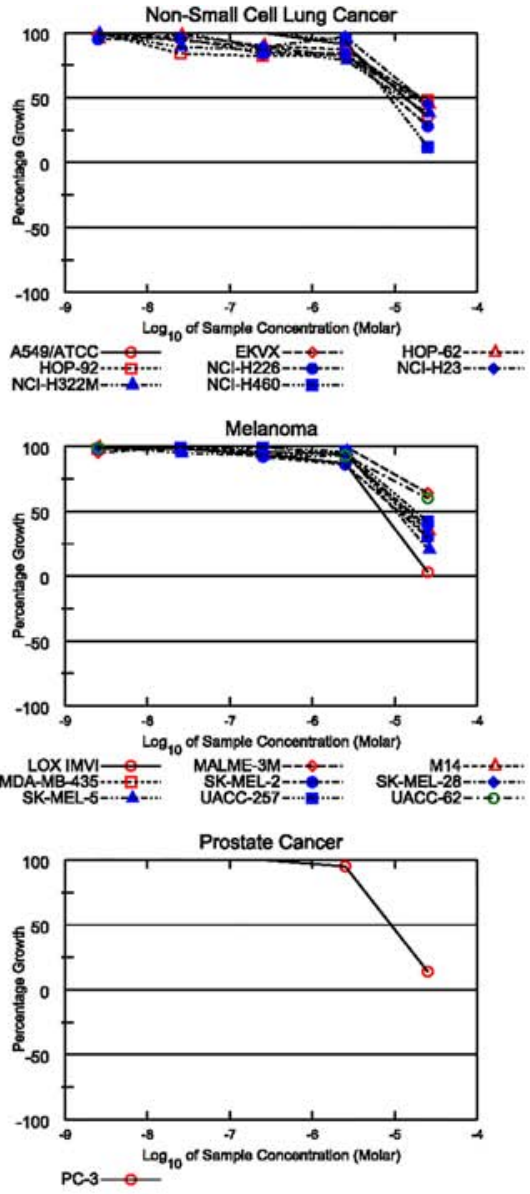
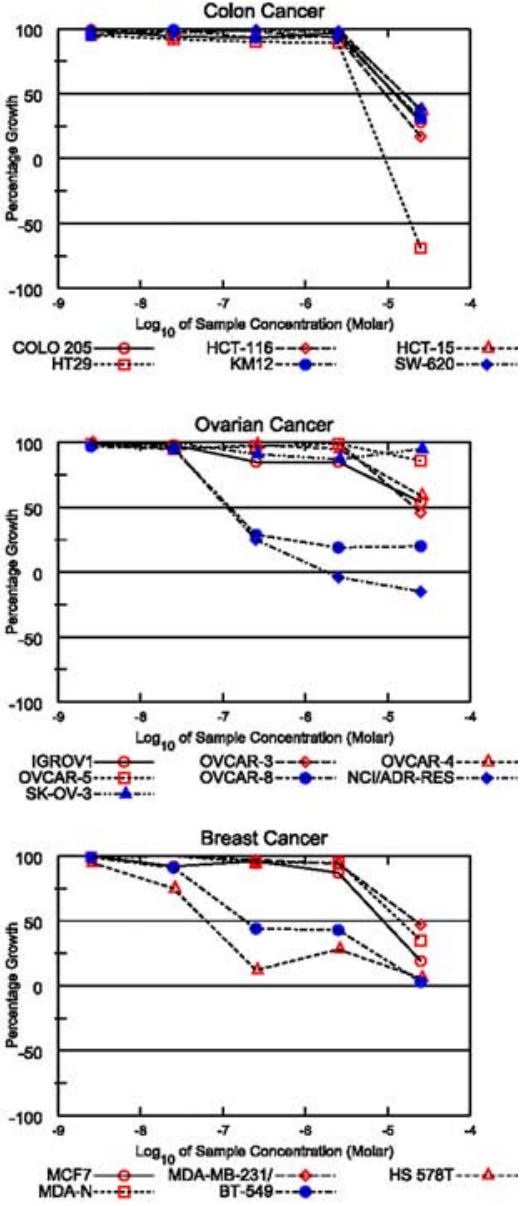

Figure 2: Tonantzitlolone has an anti-tumor effect, especially in kidney cancer cells. Similarly to englerin A [8], the cytotoxic effect of TZL in the NCI-60 tumor cell panel shows a preference for renal cancer cell lines.

in the manufacturer protocol. PKC $\alpha,-\delta$, and $\theta$ kinase assays were performed in a similar manner using $5 \mathrm{ng}$ of purified PKC proteins (incubation for $1 \mathrm{~h}$ at $30^{\circ} \mathrm{C}$ with $10 \mu \mathrm{M}$ ATP).

\section{Radioactive in vitro kinase assay}

Purified HSF1 (50 ng) was incubated with purified PKC $\theta(50 \mathrm{ng})$ in presence or absence of TZL $(1 \mu \mathrm{M})$. Reactions were initiated by the addition of $10 \mu \mathrm{M}$ nonradioactive ATP and $6 \mu \mathrm{Ci}(0.2 \mu \mathrm{M})$ of $\left[{ }^{32} \mathrm{P}\right]$-ATP and incubated at $30^{\circ} \mathrm{C}$ for $30 \mathrm{~min}$ with periodic mixing. Proteins in the kinase reactions were separated by SDS-PAGE and transferred to PVDF membrane. Phosphorylation of HSF1 was assessed by radiography of PVDF membranes. Total HSF1 was then immunoblotted to ensure equal loading.

\section{Cell lines and cell culture}

The sporadic VHL-deficient kidney tumor cell lines 786-0 and A498, and the embryonic kidney epithelial cell line HEK293 were all purchased from American Type Culture Collection (ATCC; Manassas, VA, USA).
Cells were cultured in Dulbecco's modified Eagle's medium High Glucose, pyruvate-free (DMEM; Cellgro) supplemented with $10 \%$ fetal bovine serum (Invitrogen, Grand Island, NY, USA). Viability experiments were performed in serum-free media.

\section{Analysis of cell viability in vitro}

Cell viability was assessed by Thiazolyl Blue Tetrazolium Bromide (MTT) assay as previously described [24]. Briefly 5, 000 cells/well were plated in 96-well plates and treated as indicated in the figure legends prior to assessing cell viability by MTT assay.

\section{Immunoblot analysis}

Analysis of protein expression and/or phosphorylation was made by immunoblotting as previously described [25]. Briefly, $20 \mu \mathrm{g}$ of protein were separated in 4-20\% SDS-PAGE gels (Bio-Rad, Hercules, CA, USA) and transferred onto PVDF membranes. Membranes were blocked for $1 \mathrm{~h}$ at room temperature in $5 \%$ fat-free milk diluted in TBST $(10 \mathrm{mM}$ Tris$\mathrm{HCl}, 100 \mathrm{mM} \mathrm{NaCl}, 0.5 \mathrm{M}$ EDTA, 0.1\% Tween 20). 

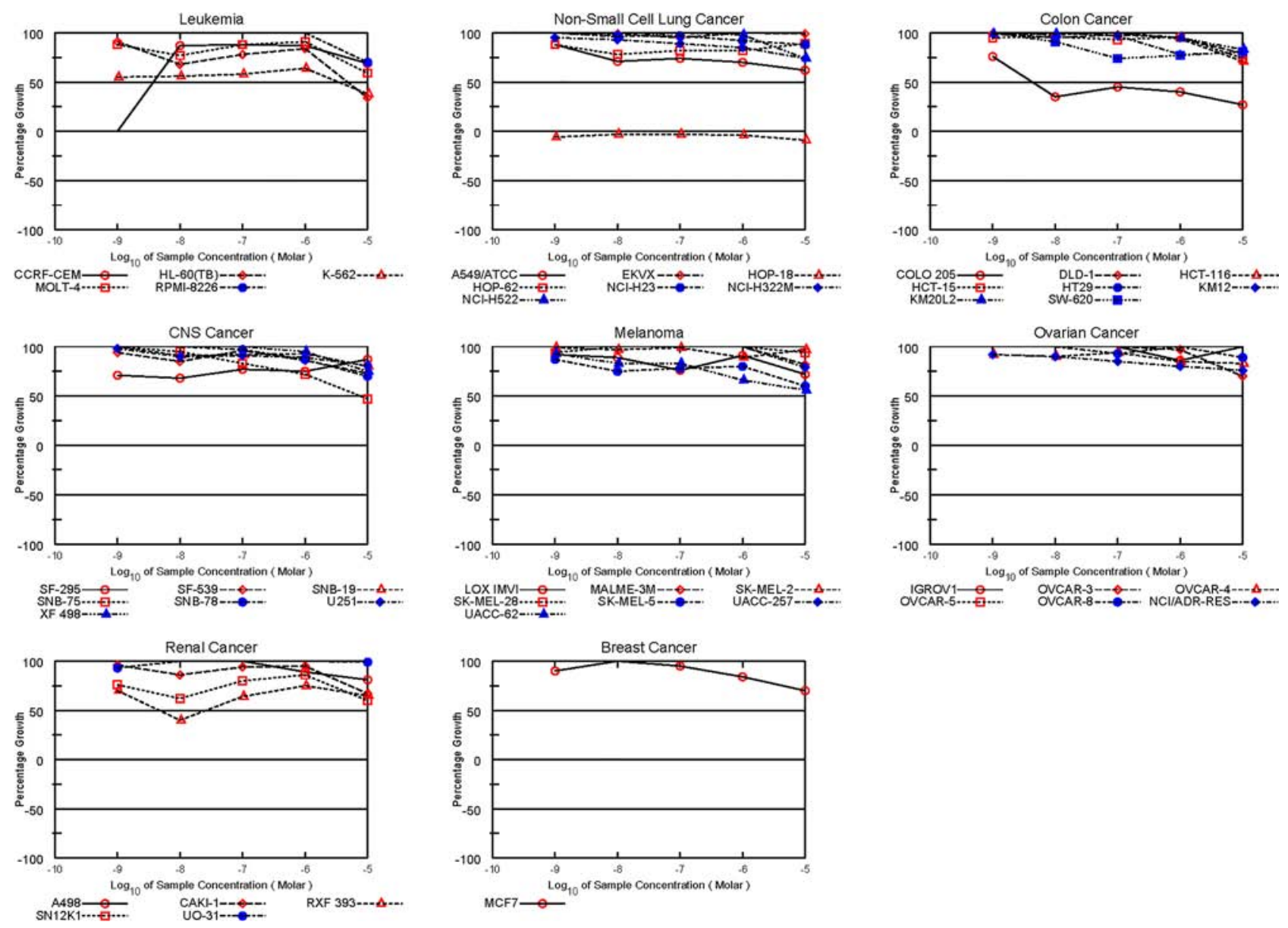

Figure 3: Effect of Bryostatin in the NCI60 cell line screen. Data about the cytotoxic effect of the pan-PKC activator bryostatin in the NCI60 tumor cell lines panel was extracted from the NCI60 database. No renal selectivity was observed.

Primary antibodies diluted in 5\% fat-free milk were incubated overnight at $4^{\circ} \mathrm{C}$. After 3 washes, horseradish peroxidase-linked secondary antibodies (Sigma-Aldrich, St Louis, MO, USA) were incubated for $1 \mathrm{~h}$ at room temperature. Signal was detected using the ECL protein detection system (Pierce, Thermo Scientific, Rockford, IL, USA). PKC $\theta$ antibody was from Abcam (Cambridge, MA); antibodies for IRS1, IRS1-ser1101, HSF1, tubulin, Akt, and p-Akt were from Cell Signaling Technology (Danvers, MA, USA); HSP70 antibody was from Thermo Scientific.

\section{Glucose uptake assay}

Glucose uptake was measured using a fluorescent non-metabolizable D-glucose analog 2-[N-(7-nitrobenz-2-oxa-1, 3-diazol-4-yl) amino]2-deoxy-D-glucose (2-NBDG, Cayman Chemicals, Ann Arbor, MI) as previously described [26]. Briefly 3, 000 cells were plated in black-well 96-well plates and were transfected the day after with small interference RNA against $\mathrm{PKC} \theta$ or $\mathrm{PKC} \alpha(10 \mathrm{nM}$; Santa Cruz Biotechnology, Dallas, TX, USA) using
Dharmafect 3 transfection reagent as recommended in the manufacturer instructions (Dharmacon, Thermo Scientific, Pittsburgh, PA, USA). Eight hours post-transfection, cells were treated as indicated (16 h). At the end of the treatment, cells were incubated for 45 minutes in KREB buffer containing $1 \mathrm{~g} / \mathrm{L}$ glucose in presence or absence of $20 \mu \mathrm{M} 2-\mathrm{NBDG}$. Cells were then washed 2 times for 10 minutes with PBS to remove all residual extracellular 2-NBDG. The amount of 2-NBDG imported into the cells was measured by assessing fluorescence at $488 \mathrm{~nm}$.

\section{HSF1 transcriptional activity reporter assay}

HSF1 transcriptional activity reporter assay was performed as previously described [4].

\section{Statistics}

Unless specified, all values are expressed as mean \pm standard error. Values were compared using the Student-Newman-Keul's test. $P<0.05$ was considered significant. 

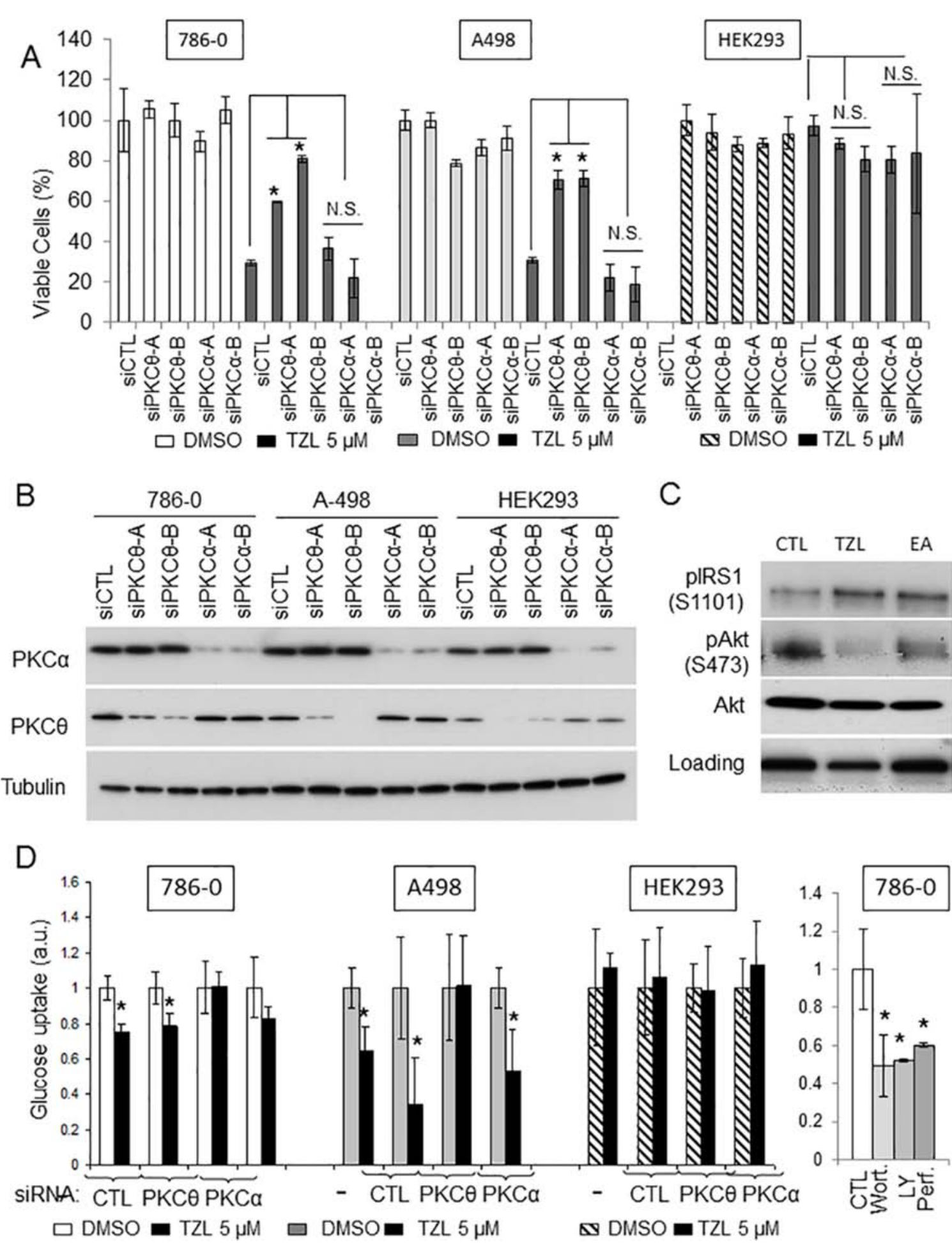

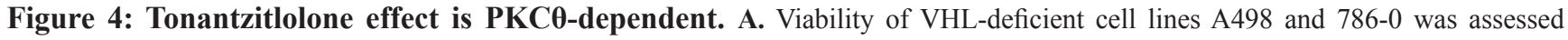
following transient silencing of PKC $\theta$ or PKC $\alpha$ using 2 distinct small interference RNAs. The embryonic kidney cell line HEK293 was used as control. B. Silencing efficiency was assessed by immunoblotting. C. Effect of TZL on the insulin pathway was assessed by immnublotting. EA was used as a positive control. D. Effect of TZL on glucose uptake was assessed in VHL-deficient 786-0 and A498 cells. The embryonic kidney cell line HEK293 and treatment of 786-0 cells with the PI3K/Akt inhibitors wortmannin, LY294002 and perifosine $(5 \mu \mathrm{M} ; 4 \mathrm{~h})$ were used as controls. ${ }^{*} p<0.05$; N.S.: non-significant; EA: englerin A; TZL: tonantzitlolone; Wort: wortmannin; LY: LY294002; Perf: perifosine. 
A

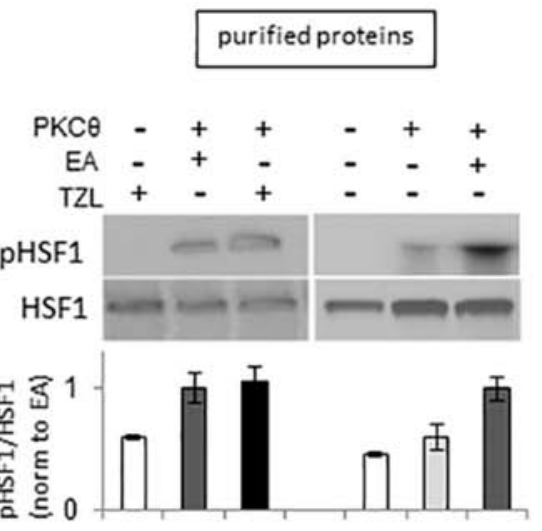

C

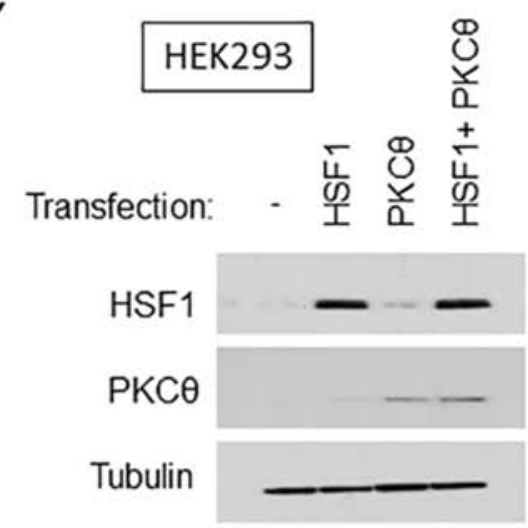

B
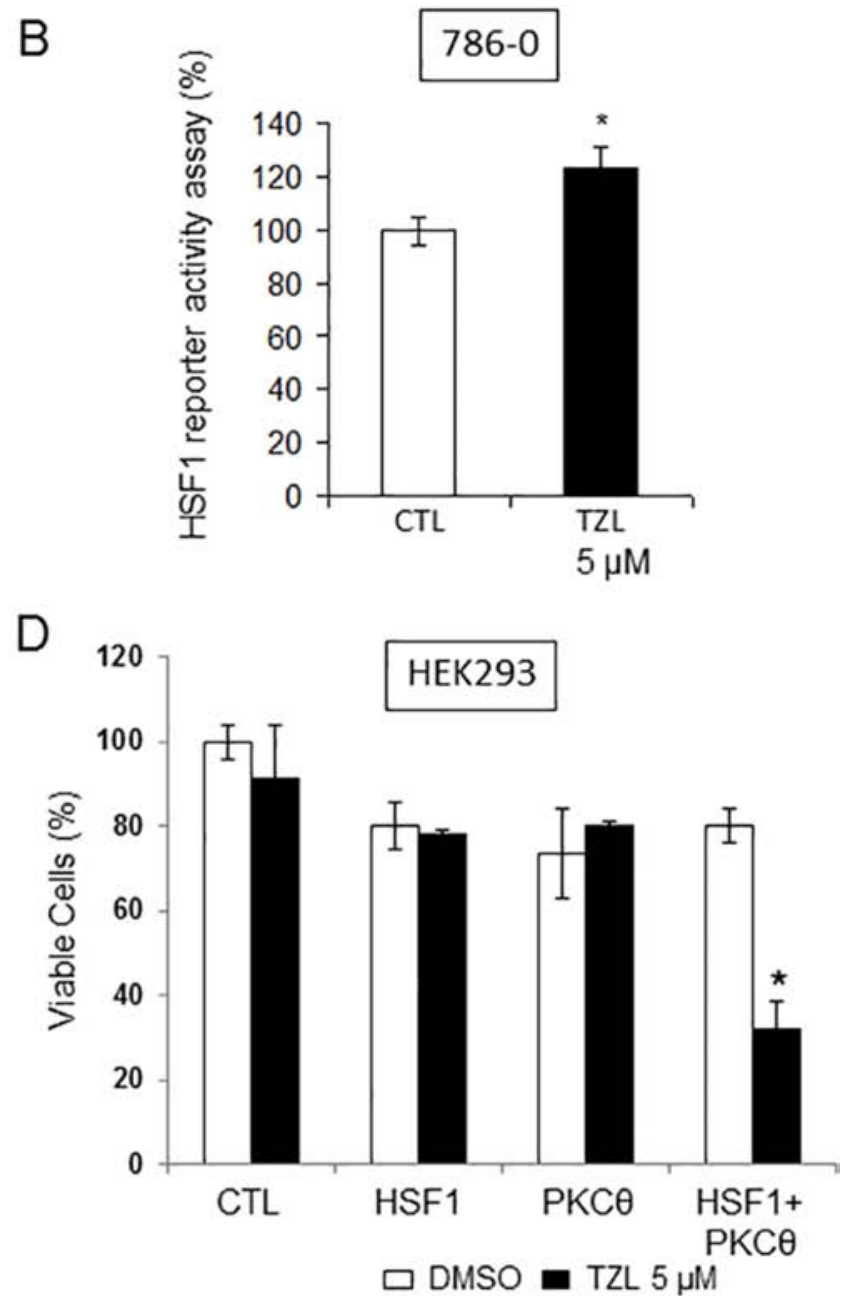

E

786-0

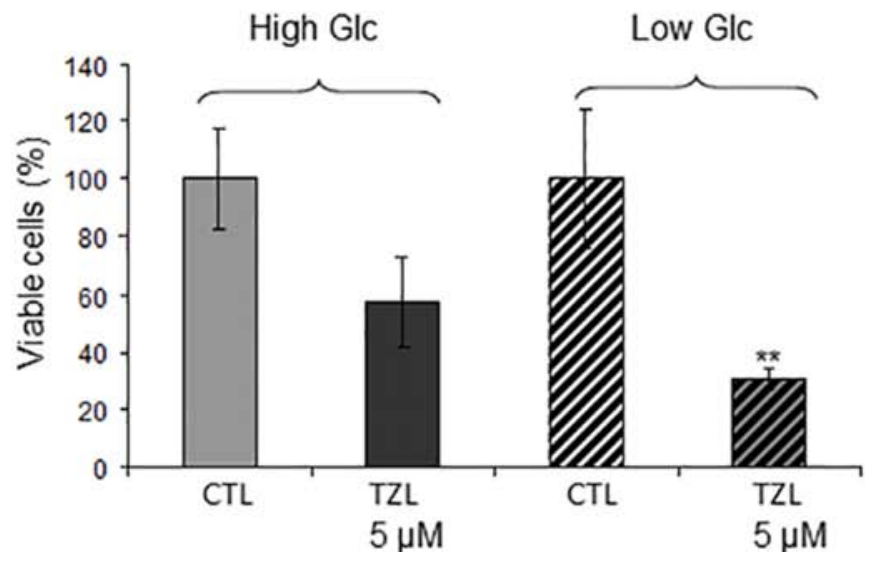

Figure 5: Tonantzitlolone activates HSF1 and induces glucose dependency. A. Radioactive kinase activity assay was performed to assess the effect of TZL $(5 \mathrm{mM})$ on PKC $\theta$-mediated phosphorylation of HSF1 in the presence of $6 \mu \mathrm{Ci}(0.2 \mu \mathrm{M})$ of $\left[{ }^{32} \mathrm{P}\right]$-ATP and $10 \mu \mathrm{M}$ non-radioactive ATP using purified PKC $\theta$ and purified HSF1 (50 ng of purified proteins; treatment for $30 \mathrm{~min}$ at $\left.30^{\circ} \mathrm{C}\right)$. EA $(0.1 \mu \mathrm{M})$ was used as positive control [4]. B. HSF1 transcriptional activity following TZL treatment $(5 \mu \mathrm{M}, 24 \mathrm{~h})$ was assessed using a luciferase reporter assay in 786-0 cells. C. Overexpression efficiency of HSF1 and PKC $\theta$ in HEK293 cells was assessed by immunoblotting 24 h posttransfection. D. Effect of TZL $(5 \mu \mathrm{M})$ on viability $24 \mathrm{~h}$ after treatment of HEK293 transfected with HSF1 and/or PKC $\theta$ (cells treated $24 \mathrm{~h}$ post-transfection). E. $786-0$ cell viability was assessed following TZL treatment $(5 \mu \mathrm{M})$ in high glucose $(4.5 \mathrm{~g} / \mathrm{L})$ or low glucose $(1 \mathrm{~g} / \mathrm{L})$ media. * $p<0.05$; EA: englerin A; TZL: Tonantzitlolone. 


\section{ACKNOWLEDGMENTS}

The authors would like to thank Dr. Dale Nagle, University of Mississippi for permission to share his data on NSC\#741581 (sodwanone W). This research was supported with funds from the Intramural Research Program, National Cancer Institute (project \# Z01 BC010683-03 [LN], project \# 1ZIABC011038-07 $[\mathrm{WML}])$. The authors declare no conflicts of interest.

\section{CONFLICTS OF INTEREST}

The authors declare no conflict of interest.

\section{REFERENCES}

1. Nelson TJ, Sun MK, Hongpaisan J, Alkon DL. Insulin, PKC signaling pathways and synaptic remodeling during memory storage and neuronal repair. Eur.J.Pharmacol. 2008; 585:76-87.

2. Idris I, Gray S, Donnelly R. Protein kinase C activation: isozyme-specific effects on metabolism and cardiovascular complications in diabetes. Diabetologia. 2001; 44:659-673.

3. Ma L, Tao Y, Duran A, Llado V, Galvez A, Barger JF, Castilla EA, Chen J, Yajima T, Porollo A, Medvedovic M, Brill LM, Plas DR, et al. Control of nutrient stress-induced metabolic reprogramming by PKCzeta in tumorigenesis. Cell. 2013; 152:599-611.

4. Sourbier C, Scroggins BT, Ratnayake R, Prince TL, Lee S, Lee MJ, Nagy PL, Lee YH, Trepel JB, Beutler JA, Linehan WM, Neckers L. Englerin A stimulates PKCtheta to inhibit insulin signaling and to simultaneously activate HSF1: pharmacologically induced synthetic lethality. Cancer Cell. 2013; 23:228-237.

5. Jasper C, Wittenberg R, Quitschalle M, Jakupovic J, Kirschning A. Total synthesis and elucidation of the absolute configuration of the diterpene tonantzitlolone. Org.Lett. $2005 ; 7: 479-482$.

6. Jasper C, Adibekian A, Busch T, Quitschalle M, Wittenberg R, Kirschning A. Total synthesis of cyclic diterpene tonantzitlolone based on a highly stereoselective substrate-controlled aldol reaction and ring-closing metathesis. Chemistry. 2006; 12:8719-8734.

7. Dai J, Fishback JA, Zhou YD, Nagle DG. Sodwanone and yardenone triterpenes from a South African species of the marine sponge Axinella inhibit hypoxia-inducible factor-1 (HIF-1) activation in both breast and prostate tumor cells. J.Nat.Prod. 2006; 69:1715-1720.

8. Wender PA, Hinkle KW, Koehler MF, Lippa B. The rational design of potential chemotherapeutic agents: synthesis of bryostatin analogues. Med.Res.Rev. 1999; 19:388-407.

9. Shoemaker RH. The NCI60 human tumour cell line anticancer drug screen. Nat.Rev.Cancer. 2006; 6:813-823.
10. Ratnayake R, Covell D, Ransom TT, Gustafson KR, Beutler JA. Englerin, A, a selective inhibitor of renal cancer cell growth, from Phyllanthus engleri. Org.Lett. 2009; 11:57-60.

11. Wender PA, Baryza JL, Brenner SE, Clarke MO, Craske ML, Horan JC, Meyer T. Function oriented synthesis: the design, synthesis, PKC binding and translocation activity of a new bryostatin analog. Curr.Drug Discov.Technol. 2004; 1:1-11.

12. Mendillo ML, Santagata S, Koeva M, Bell GW, Hu R, Tamimi RM, Fraenkel E, Ince TA, Whitesell L, Lindquist S. HSF1 drives a transcriptional program distinct from heat shock to support highly malignant human cancers. Cell. 2012; 150:549-562.

13. Dai C, Whitesell L, Rogers AB, Lindquist S. Heat shock factor 1 is a powerful multifaceted modifier of carcinogenesis. Cell. 2007; 130:1005-1018.

14. Cancer Genome Atlas Research Network. Comprehensive molecular characterization of clear cell renal cell carcinoma. Nature. 2013; 499:43-49.

15. Krieg M, Haas R, Brauch H, Acker T, Flamme I, Plate KH. Up-regulation of hypoxia-inducible factors HIF-1alpha and HIF-2alpha under normoxic conditions in renal carcinoma cells by von Hippel-Lindau tumor suppressor gene loss of function. Oncogene. 2000; 19:5435-5443.

16. Sufan RI, Jewett MA, Ohh M. The role of von Hippel-Lindau tumor suppressor protein and hypoxia in renal clear cell carcinoma. Am.J.Physiol Renal Physiol. 2004; 287:F1-F6.

17. Roe JS, Kim HR, Hwang IY, Ha NC, Kim ST, Cho EJ, Youn HD. Phosphorylation of von Hippel-Lindau protein by checkpoint kinase 2 regulates p53 transactivation. Cell Cycle. 2011; 10:3920-3928.

18. Sourbier C, Lindner V, Lang H, Agouni A, Schordan E, Danilin S, Rothhut S, Jacqmin D, Helwig JJ, Massfelder T. The phosphoinositide 3-kinase/Akt pathway: a new target in human renal cell carcinoma therapy. Cancer Res. 2006; 66:5130-5142.

19. Agell N, Jaumot M, Rodriguez-Vilarrupla A, Brun S, Abella N, Canela N, Estanyol JM, Bachs O. The diverging roles of calmodulin and $\mathrm{PKC}$ in the regulation of $\mathrm{p} 21$ intracellular localization. Cell Cycle. 2006; 5:3-6.

20. De VF, Riccardi M, Malanga D, Scrima M, De MC, Viglietto G. PKC-dependent phosphorylation of p27 at T198 contributes to p27 stabilization and cell cycle arrest. Cell Cycle. 2012; 11:1583-1592.

21. Tamura N, Sugihara K, Akama TO, Fukuda MN. Trophinin-mediated cell adhesion induces apoptosis of human endometrial epithelial cells through PKC-delta. Cell Cycle. 2011; 10:135-143.

22. Santagata S, Hu R, Lin NU, Mendillo ML, Collins LC, Hankinson SE, Schnitt SJ, Whitesell L, Tamimi RM, Lindquist S, Ince TA. High levels of nuclear heat-shock 
factor 1 (HSF1) are associated with poor prognosis in breast cancer. Proc.Natl.Acad.Sci.U.S.A. 2011; 108:18378-18383.

23. Whitesell L, Lindquist $\mathrm{S}$. Inhibiting the transcription factor HSF1 as an anticancer strategy. Expert.Opin.Ther.Targets. 2009; 13:469-478.

24. Sourbier C, Srivastava G, Ghosh MC, Ghosh S, Yang Y, Gupta G, Degraff W, Krishna MC, Mitchell JB, Rouault TA, Linehan WM. Targeting HIF2alpha translation with Tempol in VHL-deficient clear cell renal cell carcinoma. Oncotarget. 2012; 3:1472-1482.
25. Sourbier C, Valera-Romero V, Giubellino A, Yang Y, Sudarshan S, Neckers L, Linehan WM. Increasing reactive oxygen species as a therapeutic approach to treat hereditary leiomyomatosis and renal cell carcinoma. Cell Cycle. 2010; 9:4183-4189.

26. O’Neil RG, Wu L, Mullani N. Uptake of a fluorescent deoxyglucose analog (2-NBDG) in tumor cells. Mol. Imaging Biol. 2005; 7:388-392. 